\title{
PERFIL DE FORMAÇÃO DOS GESTORES ESPORTIVOS ALIADO A UMA PROPOSTA CIENTÍFICA
}

\section{Rodrigo L. Soares ${ }^{*}$, Eliana de T. Ishibashi \\ Resumo}

De modo geral, os gestores esportivos têm valorizado o investimento em sua formação. Nesse contexto, o objetivo dessa pesquisa é analisar o perfil de formação desses profissionais, a partir do referencial teórico da área (um perfil ideal) e a partir do perfil de formação de um grupo de gestores que já atua no mercado profissional com essa atribuição. Sendo assim, foi realizada uma pesquisa bibliográfica referente ao tema, e também uma pesquisa documental, com finalidade de analisar os currículos vitae de gestores que já atuam no mercado. Foi identificado que todos os gestores possuem cursos de graduação, sendo eles em áreas distintas. Porém, ainda vemos que parte desses profissionais não continuam sua formação, tornando-se, possivelmente não qualificados suficientemente para exercer tais atividades.

\section{Palavras-chave:}

Gestor esportivo, Gestão, Formação profissional, Mercado esportivo.

\section{Introdução}

Atualmente, percebe-se uma evolução nos estudos e formações referentes a área da gestão esportiva. Porém, apesar deste progresso, ainda nos deparamos com muitos profissionais não qualificados suficientemente para assumirem tais cargos. Objetivos: analisar o perfil de formação de gestores esportivos, a partir do referencial acadêmico científico da área (um perfil ideal) e o perfil de formação de um grupo de gestores que já atuam no mercado

\section{Resultados e Discussão}

$\mathrm{Na}$ pesquisa documental, foram analisados currículos vitae de 17 gestores esportivos. Identificou-se que todos os gestores que tiveram seus currículos analisados possuem cursos de graduação:

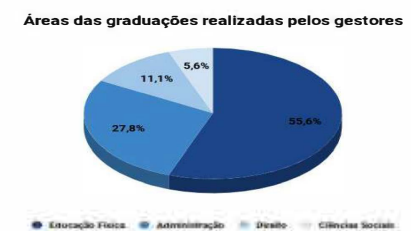

Também foram analisados aspectos referentes à formação continuada, como cursos de pós-graduação, de extensão e participação em eventos.

Percebe-se que parte dos gestores não continuam sua formação acadêmica:
Além da formação, também foram analisados aspectos referentes às experiências dos gestores.

Percebemos que as análises conferem parcialmente com o que diz Parkhouse (1996): "a carreira do gestor esportivo é fundamentada em cursos em dois pilares: Educação Física e Administração."

Ao final das análises, surge a discussão: será que apenas um curso de graduação é suficiente para atuar em cargos administrativos em entidades esportivas?

\section{Conclusões}

- Nota-se um avanço na área, na qual os profissionais estão se preparando cada vez mais para atuarem.

- Grande parte desses profissionais interrompem suas formações.

- Existe coerência, em partes, entre o referencial teórico-científico da área.

\section{Agradecimento}

- Conselho Nacional de Desenvolvimento Científico e Tecnológico - CNPq

- Pesquisadores do LAPEGI e do Sport.Map.

PIMENTA, Rogério da Costa. O Perfil Profissional do Gestor de Organizações Esportivas Brasileiras. 2001. 148 f. Dissertação (Mestrado) Curso de Administração Pública, Fundação Getúlio Vargas, Rio de Janeiro, 2001.

DA ROCHA, Cláudio Miranda; DA CUNHA BASTOS, Flávia. Gestão do esporte: definindo a área.Revista Brasileira de Educação Física e Esporte, v 25, n. spe, p. 91-103, 2011.

BARROS FILHO, Marcos Antonio et al. Perfil do Gestor Esportivo Brasileiro: uma revisão de literatura. Revista Intercontinental de Gestão Desportiva, v. 3, supl. 1, p. 44-52, 2013.

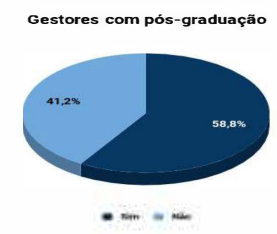

